\title{
BOOK REVIEW ESSAY: UNDERSTANDING LATIN AMERICA IN THE ERA OF GLOBALIZATION
}

\author{
Glen David Kuecker \\ DePauw University \\ Greencastle, Indiana \\ gkuecker@depauw.edu
}

Robinson, William I. 2008. Latin America and Global Capitalism: A Critical Globalization Perspective. Baltimore: The Johns Hopkins University Press. 412 Pages. ISBN-13 978-0-80189039-0. Cloth (\$55.00).

Despite the importance of globalization for understanding contemporary Latin America, we lack a comprehensive and theoretically substantive analysis of the phenomena. Duncan Green's early offering, The Silent Revolution (2003), was the lone monograph in the field, but even its second edition has become significantly dated. William I. Robinson's Latin America and Global Capitalism offers us a valuable contribution by filling the void. Robinson deploys a rigorous theoretical analysis in consideration of deep empirical data in offering explanations for why the region's free market transformation was a fiasco. The book clearly merits inclusion in the Johns Hopkins Studies in Globalization Studies series, and will stand as a benchmark for all future scholarship. When considered with Robinson's Promoting Polyarchy (1996), Transnational Conflicts (2003), and A Theory of Global Capitalism (2004), the author is now the top scholar in the field of critical globalization studies.

The first of Robinson's six chapters frames the book by placing Latin America within the context of what he describes as the "epochal shift in world capitalism." He understands contemporary globalization as constituting a new historical period, because the process of neoliberal market transformation generated the transnationalization of the elite class, corporations, and institutions of economic governance. This triad of transnationalization differs from earlier manifestations because of the scope, scale, and intensity of the process. Robinson maintains that it has generated "new forms of poverty and wealth, and new configurations of wealth and power" that carries with it a "new cartography" within the geographical divisions of the once modern world-system (p. 43). Globalization's new mapping blurs the distinctions between core, periphery, and semiperiphery through the transnational networks of capital, labor, and production. The glue holding the new globalized system together is a new a form of imperialism, itself a transnational form of hegemony. On these accounts, Robinson appears to be in camp with the post-modern wanderings of Antonio Negri and Michael Hardt's Empire (2001). Yet, Robinson's take on the transnational order, through his theory of polyarchy (defined below), keeps him firmly grounded in a radical critique of capitalism. Those familiar with Robinson's work, will see the maturation of his theoretical positions, which he now uses to set the stage for a rigorous and ambitious analysis of Latin America's experience with neoliberalism.

The book's core argument is established in the opening section of chapter two. He maintains that the political economy of globalized neoliberalism is profoundly unstable due to the deep contradictions of late capitalism. This argument, of course, has been articulated by many theorists, such as David Harvey in his classic The Condition of Postmodernity. Robinson's 
rendition of the argument has four steps. First, neoliberal globalization is vulnerable to collapse because of the highly speculative nature of the "global casino" of unregulated global finance, an argument validated by the current meltdown in global capitalism, but well anticipated by economists like David Korten in When Corporations Rule the World (2001). Second, the agricultural export sector is fragile due to unpredictable fluctuations in global supply and demand, especially the free-trade propensity toward over production. Next, Robinson maintains the neoliberal model does not account for societal needs, which stimulates discontent and conflict within the political order. Finally, he argues the neoliberal order is weak due to the vulnerabilities of the ruling elite and the increase in and novelty of social protest. These four vulnerabilities culminate at the start of the twenty-first century in a counter-hegemonic moment that finds radical alternatives to capitalism gaining power as neoliberalism falls deeper into crisis.

The balance of chapter two presents the first part of Robinson's consideration of Latin America's place in the global economy. The focus is on the agriculture sector, while chapter three considers what he calls "industrial subcontracting," along with the service sector, tourism, and migration. Robinson argues that with globalization "non-traditional agricultural exports" became the defining feature of Latin America's place within the "global supermarket." He provides several clear examples of the argument: cut flowers in Ecuador and Colombia; fruits and wines from Chile; soy from the Rio de Plata; and winter fruits and vegetables from Central America. The empirical data presented clearly and abundantly supports his main contentions about Latin American agricultural production as defined by neoliberalism. These are: transnational agribusinesses dominate; non-capitalist production methods are further displaced; such displacement results in migration; flexible labor systems dominate; women play an increasing role in the new labor regime; and local production systems are more tightly articulated to the global system. Pulling from the scholarship of particular case studies, Robinson's summary of the neoliberal agricultural political economy in Latin America is clear, precise, and substantive. It is the best statement on the topic to date.

When neoliberalism displaced the import substitution industrialization, Keynsian economic policies after the 1982 Mexican debt default Latin America experienced a transition toward a new system of production within the global economy. This new system is the topic of chapter three. Robinson's main argument here is centered on the free market system of flexible accumulation, which he contends made subcontracting, services, tourism, and migration the predominate sectors of the non-agricultural economy. While the notion of flexible accumulation has been well established by scholars like Harvey, Robinson significantly adds to our analysis with the empirical data supporting his presentation of these four sectors. Subcontracting is the part assembly sector, what is commonly known in Latin America as the "maquiladoras." Robinson's analysis illustrates the fragility of neoliberalism for countries like Mexico, where the subcontracting system has undergone major fluctuations since the $1980 \mathrm{~s}$. Vulnerable to the raceto-the-bottom, especially competition from production in China, the maquila sector is highly unstable. Its strongest base - auto parts production - was nearly eliminated with the collapse of the U.S. auto industry during this most recent crisis in global capitalism. Robinson adds to our understanding of Mexico by making a valuable analysis of subcontracting in Central America. His regional expertise is especially evident in this section. The discussion of South Korean transnationals in Guatemala, for example, offers a fascinating perspective on Latin America's new place in global capitalism, as well as the harshly exploitative quality of contemporary capitalism. 
Robinson's evaluation of the service sector merges with his consideration of tourism, which offers wonderful analysis of this globalized industry. He demonstrates how the growing tourism sector is the consequence of the free market's division of global wealth and how its disparity converges with flexible accumulation's segmented labor force. Likewise, Robinson deploys the idea of neoliberalism's segmented labor force to drive his analysis of migration. Robinson builds on the already rich migration literature by advancing the argument that transnational migration serves as a structural mechanism for mediating social conflict, because remittances allow national economies and their local communities to reproduce. Each of these sectors are, however, grossly dependent on the growth and smooth functioning of global capitalism, which left Latin America's neoliberal system fragile and vulnerable to economic downturns.

In chapter four, Robinson brings focus to the transnational process by examining the changes in class, state, and again, migration. The argument holds that with neoliberalism each became dislocated from firm anchoring in the nation-state to become fluid factors within the circulation of global capital. In the area of class, Robinson shows how free market reforms caused profound change. The proletariat was increased due to a dual process of de-peasantization - itself caused by neoliberal policies of land privatization - and the collapse of the Keynesian era's middle sector. Proletarianization, however, was characterized by excessive marginalization, which caused a growth in Latin America's informal sector. These negatives marched forward along with the continued transnationalization of the elite class, which also accompanied its radical increase in wealth. Robinson meticulously traces how the elites formed transnational groups, and advanced an agenda of taking political control of the neoliberal state throughout the region. While some argue that the neoliberal state was weakened by globalization, Robinson makes a convincing case that it was "reorientated" toward the new regime of capitalist accumulation (p. 185). The reorientation finds the state functioning as the conduit between local and global. It is the manager of the free market, especially the process of decreasing the public sector in favor of the private. This section of the chapter concludes with interesting discussions of new consumer patterns, especially the "Wal-Martization" of Latin America, and the increasingly important role of China within the region's economy. Scholars examining these topics will be well served by Robinson's pioneering analysis of these last two points.

In the second half of chapter four, in a clumsy transition, Robinson discusses labor mobility as another area of Latin America's transnationalization. Others have done pioneering work on these topics, especially Lynn Stephen (2007), and given the importance of her work, Robinson's lack reference to her is conspicuous. He does add, however, important consideration of intra-Latin American migrations, and illustrates how they are key elements to the regional labor system and neoliberal capital accumulation. His overview includes discussion of the complex ways communities in Latin America have become transnational because of globalization's deep impact on labor mobility. Robinson challenges the migration scholarship that understands transnational communities as examples of a liberating autonomy for Latin America's marginalized by emphasizing the contradictions within the transnational community process. While it manifests proactive social behavior, such migration remains vulnerable to hyper exploitation, social pathologies, and enhanced dependence on capitalist wages for subsistence. Robinson concludes: 
The argument that communities may benefit as communities [italics original] from global integration seems to me to ignore the underlying structural constraints in the global political economy that originate from without and confront local communities, and how these constraints shape class and power relations both at the local level and between the local and the global (p. 224).

This thesis nicely complements Judith Hellman's recent work on migration, The World of Mexican Migrants (2008), which adds evidence that Robinson falls in nicely within the most recent scholarship.

Chapter five is the turning point of the book. It outlines the deep contradictions of neoliberal globalization that has led to its hegemonic decline. Taking from Marx, Robinson's analysis focuses on capitalism's unavoidable tendency for crises, especially those driven by the logic of overproduction. The economic crises, Robinson maintains, deepen social marginalization that gave birth to a rupture in the neoliberal order's political legitimacy. Concerning the economic crises, he anticipates the current financial catastrophe. Escaping the problem of overproduction, capitalists entered an unprecedented period of financial speculation as the only outlet for surplus capital. He also explains how the convergence of neoliberal economic policy with neoconservative geostrategy has extended the life of capitalism by creating the economic opportunities of permanent war. Deregulation, informalization, marginalization, and feminization serve as his analytical frame for evaluating the destruction of Latin America's social fabric through the pauperization of labor. As the race-to-the-bottom found its rock bottom, the neoliberal order fell into hegemonic crisis as the legitimacy of the system crumbled with a succession of economic crises, such as Argentina's December 2001 meltdown.

Management of the crisis of legitimacy has fallen to the "polyarchy," which "refers to a system in which a small group actually rules, on behalf of capital, and participation in decision making by the majority is confined to choosing among competing elites in tightly controlled electoral processes" (p. 273). This mode of political domination grew apace with neoliberalism's ascent, and was fully hegemonic once the free market crises hit the region. For Robinson, the measure of polyarchy's hegemony was the extent to which elected governments were able to push through structural adjustment policies of the $1980 \mathrm{~s}$ and $1990 \mathrm{~s}$ without falling from power. Robinson explains that within the post bureaucratic authoritarian transition to electoral democracy was the reality of authoritarian power that deployed sophisticated mechanisms of repression to keep the marginalized from threatening the free market. The resulting astronomical levels of inequity and inequality in the relations of power could only result in the neoliberal system's loss of legitimacy, which gave rise to a new wave of popular class resistance.

Indeed, in chapter six, the people strike back, and they do so through a diversity of social movements and leftist political projects. Robinson divides the task of analyzing the scope of resistances into consideration of the "pink tide" and the proliferation of social movements, before focusing on indigenous uprisings, immigrant rights movement, and the Bolivarian revolution. $\mathrm{He}$ finds the reformist, left-of-center politics of the pink tide - Lula's Brazil, Kichner's Argentina, and Ortega's Nicaragua - to have the potential for forming a radical subjectivity within the popular classes, especially as they clash with the polyarchy for power. Yet, Robinson sees the limitations to reform: opposition to neoliberalism is not necessarily anti-capitalism. He further understands the lack of radicalism to be the cost of electoral viability, which constitutes a major demonstration of polyarchic power. The pink tide's advance, Robinson argues, was made 
possible by the groundswell of popular resistance to neoliberal policies. In his view, however, social movements are poor candidates for radical change, because they lack the ability to strike at capitalism, a job he leaves to formally organized unions that have the ability to withdraw labor from the system of production. Likewise, he finds little hope for radical change within the immigrant rights movement in the United States, because it is too vulnerable to domination and control by the neoliberal state. That leaves the Bolivarian revolution and indigenous movements like the Zapatistas as the remaining contenders for bringing about radical change in Latin America.

In Venezuela, the Bolivarian revolution has undertaken the explicit mission of building socialism for the twenty-first century. President Chavez has crafted an anti-capitalist bloc, anchored by Cuba, Bolivia, and Ecuador, that has succeeded in frustrating polyarchy's attempts at defeating it. Robinson highlights the unique feature of the revolutionary process in Venezuela as being the convergence of a horizontal, grassroots, poor-people's social movement with a vertical, top-down attempt at transforming the polyarchic state. While giving new life to socialism and clearly marking the demise of the "Washington consensus," Robinson invites us to consider the "much larger questions" (p. 340) presented by the Bolivarian revolution. Among these, he asks, "how do popular sectors push forward social change - or in the case of Venezuela, revolution without a revolutionary state?"' (p. 340). The Zapatistas of southern Mexico provide the material for addressing this question.

Robinson rejects the Zapatista attempt at having a revolution without taking state power. Despite the successes of the indigenous rebellion, he is clear:

At some point popular movements must work out how the vertical and horizontal intersect. A 'long march' through civil society may be essential to transform social relations, construct counter-hegemony from the ground up and assure popular control from below. Yet no emancipation is possible without an alternative project, and no such project is possible without addressing the matter of power of dominant groups, the organization of that power in the state (including coercive power), and the concomitant need to disempower dominant groups by seizing the state from them, dismantling it, and constructing alternative institutions (p. 342).

Robinson's critique is premised on the notion that revolutionary change is only proactive if it has a program of transformation, one that brings about "a radical redistribution of wealth and power, predicated on the construction of more authentic democratic structures" (p. 347). This requires "an organized left and a democratic socialist program" (pp. 347-348). Apparently, only the Bolivarian revolution meets his criteria.

Robinson's analysis of Latin America's amazing diversity of leftist politics reveals the ideological nature of his work. It is clear from the pictures sandwiched in the middle of the book that Robinson is an academic-activist who understands his scholarship to be part of the people's struggle against capitalism. Perhaps Robinson needed some reflection on the relationship between leftist scholars and social movements, especially considering the significant engagements on the complexities of community engaged research by scholars like Charlie Hale (2008). His silence on the subjectivities of those he writes about and how their struggle produced the knowledge related in the book corresponds to Robinson's unwillingness to engage the "cultural turn" and the rich 


\section{JOURNAL OF WORLD-SYSTEMS RESEARCH}

social movement literature that emanates from the "politics of culture and the culture of politics" (1998). Given his embrace of Gramscian theories of hegemony, it is odd that Robinson rejects having a revolution without taking power. For some on the left, the anarchy-socialism divide, remains absolute. Yet, as the fascinating dialogue between Andrej Grubacic and Staughton Lynd (2008) amply demonstrates, it is possible for anarchists and socialists to find common ground against common enemies.

To draw the theoretical discussion of revolutionary potentials to a conclusion, Robinson provides a brief mapping in the final pages of the book. He contextualizes the mapping with a general frame, one that argues that future conflicts will not be between nation-states, but between the haves and the have-nots. Within the frame of globalized class warfare, Robinson places four scenarios. The first is a Keynesian reform of capitalism. The second is a "global fascism based on a new war order" (p. 355). The third is a victory by the forces of anti-capitalism that leads to democratic socialism. The final scenario is that we are headed for what Sing Chew (2008) terms the "new Dark Ages," which is an epoch defined by the collapse of civilization. This fourth scenario raises the central point of critique of Robinson's work, as well as globalization studies.

Viewed from the new Dark Ages perspective, we need to think through the place of globalization in the current historical moment and how that helps us to evaluate the four scenarios Robinson provides. Given the reality that capitalism is not compatible with sustainability, we clearly see the folly of Keynesian reform. As evidenced by the recent bail-outs of too-big-to-fail economic sectors, we can see that Keynesian approaches keep the system in overshoot and threatens to drive the process of systemic collapse deeper and harder. The potential of global fascism is a response to the realities of the opening days of the Dark Ages. The politics of fear, the need to protect, and the logic of militarized solutions to catastrophes all make the fascist scenario a real possibility. The happier scenario of creating social democracy offers us the solution of eliminating capitalism, but it carries the major limitation of still being a modernist ideology, and as such is implicated in all the factors generating the new Dark Ages. Nothing in socialism necessarily prevents or mitigates catastrophic collapse, and many of its elements are either dependent upon or contributors to the factors of collapse. The Bolivarian revolution for example, is entirely addicted to oil and has no real blueprint for democratic socialism in our historical era defined by the perils of the end of oil. Likewise, President Correa's Ecuador has unequivocally declared that its path to socialism requires large-scale mining projects that threaten destruction of some of earth's most important ecological terrain and is contrary to the demands of Ecuador's large indigenous population.

For the past two decades the social sciences have been dominated by the globalization paradigm. It has become a meta-narrative, the way that we make sense of the complex problems generated by late modernity. There is nothing inherently flawed with the paradigm, and as Robinson's monograph illustrates it has served us well with arriving at deeper understandings of the human condition. We have to consider, however, if we have left the period of globalization behind, and if the world has entered a new era, one defined by the Dark Ages. If yes, then we need to determine if social science theory that came into being in explanation of older era realities are the best forms of knowledge to deploy in understanding the new Dark Ages. Even the "global village idiot," Thomas Friedman has moved from a highly flawed globalization meta-narrative of Lexus and the Olive Tree (2000) and The World is Flat (2006) to the new Dark Age paradigm in his The World is Hot, Flat, and Crowded. From this perspective we need to ask if Robinson is operating in the wrong meta-narrative, and if this error renders his questions, themes, analysis, 
and conclusions flawed in the face of the new Dark Age. Yet, it would be a mistake to not recognize the importance of Robinson's work. These are challenging theoretical questions, and they are ones that scholars now must contend with, especially the readers of this journal.

Latin America and Global Capitalism does provide valuable insights for thinking about social science analysis of the new Dark Ages. Robinson clearly shows the profound consequences that neoliberal globalization has had on Latin American society, politics, and economics. With its social fabric ripped to shreds, public sector debilitated, social sectors disarticulated from the state, and polyarchy entrenched, Latin America's ability to respond to the large-scale, multiple, and interconnected crises has been crippled right at the critical moment when a robust state, public sector, civil society, and citizenry is needed. Robinson's work is critical, then, for understanding this context, because he so clearly shows where we came from as we enter the new epoch. The catastrophic consequences of policies created by Adam Smith's invisible hand are now painfully obvious in the examples of Katrina and British Petroleum's deep sea drilling calamity. As we move deeper into the new Dark Age, such consequences will increase in frequency and severity. Neoliberal globalization's destruction of the Latin American commons means the region is less resilient in the face of the shocks of catastrophic collapse. These scenarios raise significant questions about Robinson's embrace of the Bolivarian revolution and rejection of the autonomous movements like the Zapatistas. Given Chavez's petroleum drenched clutch on the destructive forces of modernity, we might wonder if the Zapatista path of changing the world without taking power is the path of greater resilience in a global system catastrophically collapsing.

\section{References}

Alvarez, Sonia, E. Dagnino, and Arturo Escobar. Editors. 1998. Cultures of Politics Politics of Cultures: Re-Visioning Latin American Social Movements. Boulder, Co: Westview Press.

Chew, Sing. 2008. Ecological Futures: What History Can Teach Us. Lanham, MD: AltaMira Press.

Friedman, Thomas L. 2000. Lexus and the Olive Tree. New York: Anchor Books. . 2006. The World is Flat: A Brief History of the Twenty-First Century. New York: Farrar, Straus, and Giroux.

2008. The World is Hot, Flat, and Crowded: Why We Need a Green Revolution--and How It Can Renew America. New York: Farrar, Straus and Giroux.

Green, Duncan. 2003. The Silent Revolution: The Rise and Crisis of Market Economics in Latin America. Second edition. New York: Monthly Review Press.

Grubacic, Andrej and Staughton Lynd. 2008. Wobblies \& Zapatistas: Conversations on Anarchism, Marxism, and Radical History. Oakland, CA: PM Press.

Hale, Charlie. 2008. Editor. Engaging Contradictions: Theory, Politics, and Methods of Activist Scholarship. Berkeley: University of California Press.

Harvey, David. 1989. The Condition of Postmodernity: An Enquiry into the Origins of Cultural Change. London: Blackwell.

Hellman, Judith A. 2008. The World of Mexican Migrants: The Rock and the Hard Place. New York: The New Press.

Korten, David. 2001. Second Edition. When Corporations Rule the World. West Hartford, CT: Kumarian Press. 


\section{JOURNAL OF WORLD-SYSTEMS RESEARCH}

Robinson, William J. 1996. Promoting Polyarchy: Globalization, U.S. Intervention, and Hegemony. Cambridge: Cambridge University Press.

. 2003. Transnational Conflicts: Central America, Social Change, and Globalization. London: Verso.

. 2004. A Theory of Global Capitalism: Production, Class, and State in a Transnational World. Baltimore: Johns Hopkins University Press.

Stephen, Lynn. 2007. Transborder Lives: Indigenous Oaxacans in Mexico, California, and Oregon. Durham, NC: Duke University Press. 